Jurnal Inkofar * Volume 1 No. 1, Juli 2017 * ISSN: 2615-3645 (Print) / 2581-2920 (Online)

Tersedia secara online di: http://www.politeknikmeta.ac.id/meta/ojs/

\title{
PERANCANGAN APLIKASI SISTEM PENGAMBILAN KEPUTUSAN DALAM PENERIMAAN ANGGOTA BARU PADA UKM IT CYBERNETIX MENGGUNAKAN METODE ANALYTIC HIERARCHY PROCESS DENGAN BAHASA PEMROGRAMAN PHP \& MYSQL
}

\author{
Irfandi Ricon ${ }^{1)}$, Rini Sovia, S.Kom, M.Kom ${ }^{2)}$, Shary Armonitha Lusinia, S.Kom, M.Kom ${ }^{3)}$ \\ Teknik Informatika, Fakultas Ilmu Komputer, Universitas Putra Indonesia “YPTK” Padang, \\ Jl. Raya Lubuk Begalung, Padang, Sumbar-Indonesia, 25221 \\ Email : irfandi,ricon@gmail.com ${ }^{1)}$, rini_sovia4@ymail.com ${ }^{2)}$, \\ shary21armansyah@gmail.com ${ }^{3)}$
}

\begin{abstract}
ABSTRAK
Perencanaan dan usaha pemenuhan kebutuhan Sumber Daya Manusia, yang dilakukan dalam seleksi, bila dikelola secara profesional akan sangat menentukan mutu dan kesuksesan organisasi. Dengan kata lain seleksi yang efektif akan memperoleh sumber daya yang baik untuk jangka waktu yang lebih panjang. Dalam penelitian ini akan dibuat sebuah sistem pendukung keputusan untuk memudahkan pihak panitia penerimaan dalam proses seleksi calon anggota baru, khususnya pada proses penilaian dari beberapa tes yang telah dilaksanakan. Tes yang dilakukan secara umum akan menunjukkan keadaan emosional seseorang, walaupun tidak selalu demikian. Ini menunjukkan bahwa seorang calon anggota juga akan berhasil jika di dalam diri mereka terbentuk nilai-nilai yang tinggi. Penilaian dan pertimbangan dari hasil tes harus dilakukan secara berhati-hati dan dengan metode yang tepat. Laporan ini memanfaatkan Analytical Hierarchi Process (AHP) sebagai model Sistem Pendukung Keputusan (SPK). Dalam aplikasi ini, pengguna diijinkan untuk menentukan kriteria apa saja yang dipakai beserta bobot dari kriteriakriteria tersebut. Dengan perpaduan antara data kriteria serta bobot yang dimasukkan pengguna dengan data mahasiswa yang telah ada pada panitia penerimaan, aplikasi akan mampu menghasilkan rangking masing-masing calon anggota berdasarkan besarnya nilai akhir. Semakin besar nilai seorang calon anggota maka semakin bagus rangking yang diberikan berarti pula semakin sesuai dengan kriteria yang diharapkan oleh organisasi. Proses penilaian akan dilakukan dengan menggunakan aplikasi berbasis web yang menggunakan bahasa pemrograman PHP serta tempat penyimpananan segala data yang berkaitan dengan data penerimaan.
\end{abstract}

Kata Kunci: Sumber Daya Manusia, SPK, Kriteria, Organisasi, AHP, PHP, MySQL

\section{PENDAHULUAN}

UKM IT Cybernetix merupakan salah satu Unit Kegiatan Mahasiswa Universitas Putra Indonesia "YPTK" Padang yang mengkhususkan kegiatannya pada bidang Ilmu Teknologi. Di UKM IT Cybernetix terdapat beberapa unit kerja yang menjadi konsentrasi anggotanya dalam melakukan pembelajaran, seperti unit kerja programming, multimedia, jaringan, sistem operasi, hardware, dan web design. Di dalam organisasi UKM IT Cybernetix ini, setiap anggota dapat mempelajari dan mengembangkan bakat dan minatnya secara bebas dan mendalam, hal ini bertujuan untuk membantu anggota dalam pengaplikasian unit kerja yang dipilihnya. UKM IT Cybernetix dalam setiap penerimaan anggota baru selalu mengadakan seleksi anggota baru dari awal penerimaan hingga seleksi terakhir yang telah ditentukan. Dan ada beberapa kendala yang sering dihadapi dalam penerimaan anggota baru ini, berupa banyaknya pertimbangan dari panitia penerimaan dalam menentukan apakah anggota baru ini dapat diterima atau ditolak sesuai dengan hasil musyawarah yang dilakukan oleh pantia penerimaan yang masih secara manual. Untuk itu dirancang sebuah system penunjang keputusan yang dapat mengelola dan memudahkan panitia penerimaan untuk mengambil keputusan terkait dengan diseleksinya terlebih dahulu oleh sistem.

\subsection{Sistem Pengambilan Keputusan}

Sistem berbasis model yang terdiri dari prosedur-prosedur dalam pemrosesan data dan pertimbangan untuk membantu manajer dalam pengambilan keputusan (Irfan Subakti, 2002) 
menyatakan ada juga definisi yang menyatakan bahwa Decision Support System (DSS) adalah sistem berbasis komputer yang terdiri dari 3 komponen interaktif, yaitu:

a. Sistem bahasa, mekanisme yang menyediakan komunikasi diantara user dan berbagai komponen dalam DSS.

b. Knowledge system, penyimpanan knowledge domain permasalahan yang ditanamkan dalam $D S S$, baik sebagai data ataupun prosedur.

c. Sistem pemrosesan permasalahan, link diantara dua komponen, mengandung satu atau lebih kemampuan memanipulasi masalah yang dibtuhkan untuk pengambilan keputusan.

\subsection{Analytic Hierarchy Process (AHP)}

Ketika keputusan yang akan diambil bersifat kompleks dengan risiko yang besar seperti perumusan kebijakan, pengambil keputusan sering memerlukan alat bantu dalam bentuk analisis yang bersifat ilmiah, logis, dan terstruktur/konsisten. Salah satu alat analisis tersebuat adalah berupa decision making model (model pembuatan keputusan) yang memungkinkan mereka untuk membuat keputusan untuk masalah yang bersifat kompleks (Hilyah Magdalena, 2012:51).

Ciri khas suatu DSS adalah digunakannya model yang salah satu fungsinya untuk penyederhanaan masalah. AHP ynag dikembangkan oleh Thomas L Saaty merupakan model hierarki fungsional dengan input utamanya persepsi manusia. Dengan adanya hierarki masalah yang kompleks atau tidak terstruktur dipecah dalam sub-sub masalah kemudian disusun menjadi suatu berntuk hierarki (Abdul Syukur, dkk, 2010:105).

AHP sering digunakan sebagai metode pemecahan masalah dibanding dengan metode yang lain karena alasan-alasan sebagai berikut : (Hilyah Magdalena, 2012:51).

a. Struktur yang hierarki, sebagai konsekuensi dari kriteria yang dipilih, sampai pada subkriteria yang paling dalam.

b. Memperhitungkan validitas sampai dengan batas toleransi inkonsistensi sebagai kriteria dan alternatif yang dipilih oleh pengambil keputusan.

c. Memperhitungkan daya tahan output analisis sensitivitas pengambilan keputusan.

Adapun langkah-langkah dalam metode AHP adalah sebagai berikut : (Abdul Syukur, dkk, 2010:105).

a. Mendefinisikan masalah dan menentukan solusi yang diinginkan.

b. Membuat struktur hierarki, yang diawali dengan tujuan umum, dilanjutkan dengan sub-sub tujuan, kriteria dan kemungkinan alternative pada tingkatan kriteria yang paling bawah.

c. Membuat matriks perbandingan berpasangan yang menggambarkan kontribusi relative pengaruh setiap elemen terhadap masing-masing tujuan kriteria yang setingkat diatasnya. Perbandingan berdasarkan "judgement" dari pengambil keputusan dengan menilai tingkat kepentingan suatu elemen dibandingkan elemen lainnya.

d. Melakukan perbandingan berpasangan sehingga diperoleh judgment seluruhnya sebanyak $n x$ [(n-1)/4].

e. Menghitung nilai eigen dan menguji konsistensinya, jika tidak konsisten maka pengambilan data diulangi.

1) Mengulangi langkah 3, 4, dan 5 untuk seluruh tingkat hierarki.

2) Menghitung vektor eigen dari setiap matriks perbandingan berpasangan. Nilai vektor eigen merupakan bobot setiap elemen. Langkah ini untuk mensistensis judgment dalam penentuan prioritas elemen-elemen pada tingkat hierarki terendah sampai pencapaian tujuan.

3) Memeriksa konsistensi hierarki. Jika nilainya lebih dari 10\% maka penilaian data judgment harus diperbaiki.

Dengan naluri manusia dapat memperkirakan besaran sederhana melalui inderanya. Proses yang mudah adalah dengan membandingkan dua hal dengan keakuratan perbandingan yang dapat dipertanggung jawabkan. Untuk menilai perbandingan tingkat kepentingan elemen, Saaty (1980) menetapkan skala kuantitatif 1 sampai 9 seperti tabel dibawah ini :

Tabel 1. Skala Kuantitatif

\begin{tabular}{|c|c|}
\hline $\begin{array}{c}\text { Intensitas } \\
\text { Kepentingan }\end{array}$ & Keterangan \\
\hline 1 & Kedua elemen sama pentingnya \\
\hline
\end{tabular}


Jurnal Inkofar * Volume 1 No. 1, Juli 2017 * ISSN: 2615-3645 (Print) / 2581-2920 (Online)

Tersedia secara online di: http://www.politeknikmeta.ac.id/meta/ojs/

\begin{tabular}{|c|l|}
\hline 3 & $\begin{array}{l}\text { Elemen yang satu sedikit lebih } \\
\text { penting dari pada elemen } \\
\text { lainnya. }\end{array}$ \\
\hline 5 & $\begin{array}{l}\text { Elemen yang satu lebih penting } \\
\text { dari pada elemen lainnya }\end{array}$ \\
\hline 7 & $\begin{array}{l}\text { Satu elemen jelas lebih mutlak } \\
\text { penting dari pada elemen } \\
\text { lainnya. }\end{array}$ \\
\hline 9 & $\begin{array}{l}\text { Satu elemen mutlak penting dari } \\
\text { pada elemen lainnya. }\end{array}$ \\
\hline $2,4,6,8$ & $\begin{array}{l}\text { Nilai-nilai antara dua nilai } \\
\text { pertimbangan yang berdekatan }\end{array}$ \\
\hline
\end{tabular}

Skala nilai diatas digunakan untuk mengisi nilai matrik perbandingan berpasangan yang akan menghasilkan prioritas (bobot/nilai kepentingan) masing-masing kriteria dan subkriteria.

\subsection{PHP}

PHP merupakan bahasa pemograman yang paling sering digunakan dalam pemograman web karena merupakan bahasa pemograman open source, sehingga para pemrogram tidak perlu membeli lisensi untuk membuat aplikasi web. Rasmus Leadorf merupakan orang yang membuat PHP pada tahun 1995. pada waktu itu, nama PHP adalah FI (Form Interpreted) yang merupakan sekumpulan script, digunakan untuk mengolah data form dari web. Pada perkembangan berikutnya, Rasmus akhirnya melepas kode sumber tersebut dan diberi nama PHP (Personal Home Page). Dengan berubahnya kode program menjadi open source, maka banyak pemrogram tertarik dalam mengembangkan PHP. (I Komang Setia Buana, 2014:1).

Rilis pertama PHP adalah PHP 2.0, pada bulan November 1997. Pada rilis ini, interpreter sudah bisa diimplementasikan ke bahasa C. Di dalam versi ini sudah ditambahkan modul-modul ekstensi yang menyebabkan kemampuan PHP lebih baik. Pada tahun yang sama, sebuah perusahaan bernama Zend menulis ulang interpreter PHP menjadi lebih bersih, lebih baik, dan lebih cepat. Sehingga pada bulan Juni 1998, perusahaan tersebut akhirnya merilis versi baru dari PHP dengan nama PHP 3.0 dan mengubah kepanjangan PHP menjadi Hypertext Preprocessor. Pertengahan tahun 1999, Zend merilis versi baru dari PHP dan diberi nama PHP 4.0. PHP 4.0 merupakan versi PHP yang paling banyak dipakai oleh programming karena bisa digunakan untuk membuat aplikasi web yang lebih kompleks tetapi memiliki kecepatan proses dan stabilitas yang tinggi. Pada perkembangan berikutnya, Zend akhirnya merilis versi baru lagi dengan nama PHP 5.0 pada bulan Juni 2014. Versi ini merupakan versi mutakhir dari PHP dan sudahmenerapkan model pemograman berorientasi objek yang merupakan model yang banyak dikembangkan di semua bahasa pemograman. PHP group kini sudah merilis versi baru dari PHP, yaitu versi 5.1.6.

\subsection{MySQL}

MySQL merupakan database server yang paling sering digunakan dalam pemrograman PHP. MySQL digunakan untuk menyimpan data di dalam database dan memanipulasi data-data yang diperlukan. Manipulasi data tersebut berupa, menambah, mengubah, dan menghapus data yang berada dalam database. (I Komang Setia Buana, 2014:2:)

Database sering didefinisikan sebagai kumpulan data yang terkait. Secara teknis, yang berada dalam sebuah database adalah sekumpulan tabel atau objek lain (indeks, view, dan lain-lain). Tujuan utama pembuatan database adalah untuk memudahkan dalam mengakses data. Data dapat ditambahkan, diubah, dihapus, atau dibaca dengan relatif mudah dan cepat (Abdul Kadir, 2009:14). MySQL merupakan software yang tergolong database server dan bersifat open source. Open source menyatakan bahwa software ini dilengkapi dengan source kode, selain tentu saja bentuk executable-nya atau kode yang dapat dijalankan secara langsung dalam sistem operasi, dan bisa diperoleh dengan cara mengunduh di internet secara gratis. Hal menarik lainnya adalah MySQL juga bersifat multiplatform. MySQL dapat dijalankan pada berbagai sistem operasi. (Abdul Kadir,2009:15). 


\subsection{UML (Unified Modelling Language)}

UML (Unified Modelling Language) adalah keluarga notasi grafis yang didukung oleh meta model tunggal yang membantu pendeskripsian dan desain sistem perangkat lunak, khususnya sistem yang dibangun menggunakan pemrograman berbasis objek (OOP). Definisi ini merupakan definisi yang sederhana. Pada kenyataannya, pendapat orang-orang tentang UML berbeda satu sama lain. Hal ini dikarenakan oleh sejarahnya sendiri dan oleh perbedaan persepsi tentang apa yang membuat sebuah proses rancang bangun perangkat lunak efektif. (Martin Fowler, 2004:1) UML merupakan bahasa visual untuk pemodelan dan komunikasi mengenai sebuah sistem dengan menggunakan diagram dan teks-teks pendukung (Rosa A.S dan M. Shalahuddin, 2013:137). UML muncul karena adanya kebutuhan pemodelan visual untuk menspesifikasikan, menggambarkan, membangun, dan dokumentasi dari sistem perangkat lunak. UML hanya berfungsi untuk melakukan pemodelan. Jadi, penggunaan UML tidak terbatas pada teknologi tertentu, meskipun pada kenyataannya UML paling banyak digunakan pada metodologi berorientasi objek.

\section{METODE PENELITIAN}

\subsection{Penerapan AHP}

Pada dasarnya, AHP merupakan metode yang digunakan untuk memecahkan masalah yang kompleks dan tidak terstruktur ke dalam kelompok - kelompoknya, dengan mengatur kelompok tersebut ke dalam struktur hirarki. Struktur hirarki adalah suatu model yang memberikan kesempatan bagi perorangan atau kelompok untuk membangun gagasan-gagasan dan mendefinisikan persoalan dengan cara membuat asumsi mereka masing-masing dan memperoleh pemecahan yang diinginkan darinya. Dengan cara menyusun tujuan utama sebagai level teratas akan disusun level hirarki yang berada di bawahnya yaitu kriteria-kriteria yang cocok untuk mempertimbangkan atau menilai alternatif yang kita berikan dan menentukan alternatif tersebut. Tiap-tiap kriteria mempunyai intensitas yang berbeda-beda seperti pada gambar berikut ini:

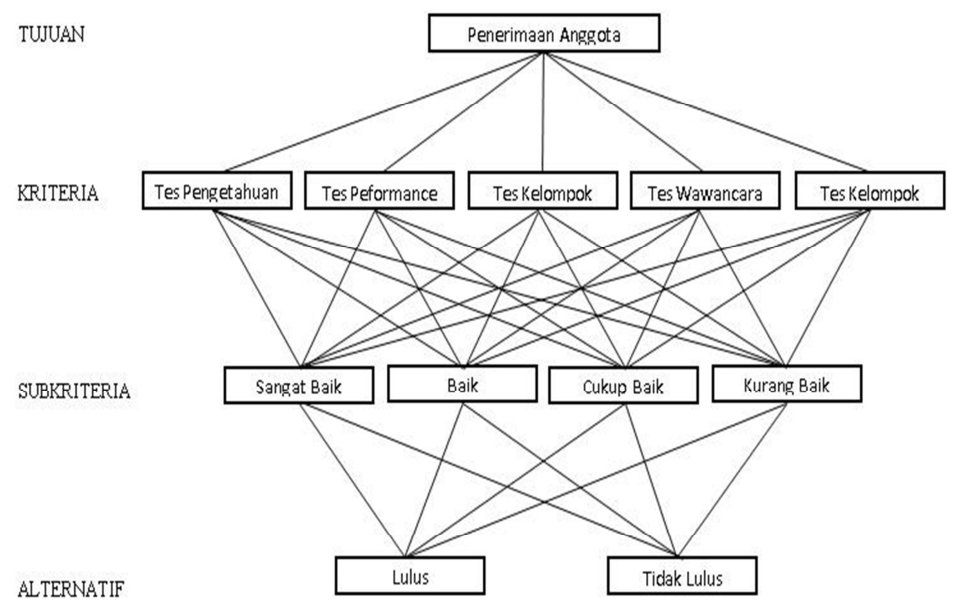

Gambar 1. Struktur Hirarki SPK Penerimaan

\subsection{Penilaian Kriteria AHP}

Untuk lebih memudahkan dalam menganalisa maka penulis memberikan penamaan pada masingmasing tes, lihat keterangan dibawah ini:
A : Tes Pengetahuan
B : Tes Performance
$\mathrm{C}:$ Tes Wawancara
D : Tes Kehadiran
E : Tes Kelompok 
Jurnal Inkofar * Volume 1 No. 1, Juli 2017 * ISSN: 2615-3645 (Print) / 2581-2920 (Online)

Tersedia secara online di: http://www.politeknikmeta.ac.id/meta/ojs/

1. Matriks perbandingan berpasangan nilai kriteria

Pada tahap ini dilakukan penilaian perbandingan antara satu kriteria dengan kriteria yang lain. Hasil penilaian kriteria dapat dilihat dalam tabel berikut:

Tabel 2. Matriks PerbandinganBerpasangan Kriteria

\begin{tabular}{|c|c|c|c|c|c|}
\hline Kriteria & A & B & C & D & E \\
\hline A & 1 & 3 & 4 & 5 & 0,50 \\
\hline B & 0,33 & 1 & 3 & 4 & 0,33 \\
\hline C & 0,25 & 0,33 & 1 & 3 & 0,25 \\
\hline D & 0,20 & 0,25 & 0,33 & 1 & 0,20 \\
\hline E & 2 & 3,00 & 4,00 & 5,00 & 1 \\
\hline Jumlah & 3,78 & 7,58 & 12,33 & 18,00 & 2,28 \\
\hline
\end{tabular}

Angka 1 pada kolom pengetahuan pada baris pengetahuan menggambarkan tingkat kepentingan yang sama antara pengetahuan dengan pengetahuan. Sedangkan angka 3 pada kolom performance baris pengetahuan menunjukan bahwa Performance sedikit lebih penting dibandingkan pengetahuan. Angka 0,33 kolom pengetahuan baris performance merupakan hasil perhitungan angka 1 pada baris dan kolom pengetahuan dibagi dengan 3 angka pada baris pengetahuan kolom performance. Sedangkan angka yang lain diperoleh dengan cara yang sama.

2. Membuat matriks nilai kriteria. Matriks ini diperoleh dengan rumus sebagai berikut:

a. Nilai baris kolom baru = nilai baris kolom lama (tabel matrik perbandingan berpasangan) / jumlah masing kolom lama (tabel matrik perbandingan berpasangan).

b. Nilai kolom jumlah tabel matrik nilai kriteria diperoleh dari penjumlahan nilai pada tiap baris tabel tersebut. $(0,26+0,40+0,32+0,28+0,22=1,48)$.

c. Nilai prioritas pada tabel matrik nilai kriteria diperoleh dari pembagian kolom jumlah dibagi jumlah kriteria.

Hasil perhitungan bisa dilihat pada Tabel 3 berikut:

Tabel 3. Perhitungan prioritas nilai kriteria

\begin{tabular}{|c|c|c|c|c|c|}
\hline Kriteria & A & B & C & D & E \\
\hline A & 0,26 & 0,40 & 0,32 & 0,28 & 0,22 \\
\hline B & 0,09 & 0,13 & 0,24 & 0,22 & 0,15 \\
\hline C & 0,07 & 0,04 & 0,08 & 0,17 & 0,11 \\
\hline D & 0,05 & 0,03 & 0,03 & 0,06 & 0,09 \\
\hline E & 0,53 & 0,40 & 0,32 & 0,28 & 0,44 \\
\hline
\end{tabular}

3. Membuat matriks penjumlahan setiap baris

Matrik ini dibuat dengan mengalikan nilai prioritas pada tabel matrik nilai kriteria dengan matrik perbandingan berpasangan. Hasil perhitungannya dapat dilihat pada tabel berikut :

Tabel 4. Perhitungan matrik kriteria penjumlahan setiap baris

\begin{tabular}{|c|c|c|c|c|c|}
\hline & A & B & C & D & E \\
\hline A & 0,30 & 0,50 & 0,37 & 0,26 & 0,20 \\
\hline B & 0,10 & 0,17 & 0,28 & 0,20 & 0,13 \\
\hline C & 0,07 & 0,06 & 0,09 & 0,15 & 0,10 \\
\hline D & 0,06 & 0,04 & 0,03 & 0,05 & 0,08 \\
\hline E & 0,59 & 0,50 & 0,37 & 0,26 & 0,39 \\
\hline
\end{tabular}


Nilai 0,30 pada baris dan kolom pengetahuan didapat dari perkalian antara nilai prioritas baris pengetahuan pada tabel matrik nilai kriteria dikalikan dengan nilai baris - kolom pengetahuan pada tabel matrik perbandingan berpasangan. Nilai yang lain diperoleh dengan cara yang sama. Nilai jumlah didapat dari penjumlah nilai pada masing-masing baris kriteria.

4. Perhitungan rasio konsistensi

Perhitungan ini digunakan untuk memastikan bahwa nilai rasio kosistensi $(\mathrm{CR})<=0,1$ jika nilainya lebih besar dari 0,1 maka matrik perbandingan berpasangan perlu diperbaiki. Untuk menghitung rasio kosistensi dibuat Tabel 5 seperti berikut :

Tabel 5. Perhitungan CR kriteria

\begin{tabular}{|c|c|c|c|}
\hline Kriteria & Jumlah & Prioritas & Hasil \\
\hline A & 1,62 & 0,30 & 1,92 \\
\hline B & 0,88 & 0,17 & 1,05 \\
\hline C & 0,47 & 0,09 & 0,57 \\
\hline D & 0,26 & 0,05 & 0,31 \\
\hline E & 2,11 & 0,39 & 2,51 \\
\hline
\end{tabular}

Kolom jumlah per baris diperoleh dari kolom jumlah pada tabel penjumlah setiap baris, sedangkan kolom prioritas diperoleh dari kolom prioritas tabel matrik nilai kriteria.dari tabel diatas diperoleh nilai berikut :

Jumlah (penjumlahan dari nilai hasil) $=6,35$,

$\mathrm{n}$ (jumlah kriteria) $=5$

$\lambda$ maks (jumlah $/ \mathrm{n})=1,2706$

CI $(\lambda$ maks $-\mathrm{n}) /(\mathrm{n}-1)=-0,932$

$\mathrm{CR}(\mathrm{CI} / \mathrm{IR}$ (lihat pada tabel index random) $=-0.832$

Tabel index random (IR) dapat dilihat sebagai berikut :

Tabel 6. Index Random (IR)

\begin{tabular}{|l|c|c|c|c|c|c|c|c|c|c|}
\hline 1 & 2 & 3 & 4 & 5 & 6 & 7 & 8 & 9 & 10 & \\
\hline 0 & 0 & 0.58 & 0.9 & 1.12 & 1.24 & 1.32 & 1.41 & 1.45 & 1.49 & \\
\hline
\end{tabular}

\subsection{Penilaian $S u b$ Kriteria AHP}

Oleh karena nilai $\mathrm{CR}<=0,1$, maka rasio kosistnsi perhitungan dapat diterima.

Untuk lebih memudahkan dalam menganalisa maka penulis memberikan penamaan pada masingmasing tes, lihat keterangan dibawah ini :

A : Sangat Baik

B : Baik

C : Cukup Baik

D: Kurang Baik

1. Matriks perbandingan berpasangan sub kriteria tes pengetahuan

Hasil penilaian kriteria dapat dilihat dalam tabel berikut :

Tabel 7. Matrik perbandingan berpasangan sub kriteria

\begin{tabular}{|c|c|c|c|c|}
\hline & A & B & C & D \\
\hline A & 1 & 3 & 4 & 6 \\
\hline B & 0,33 & 1 & 3 & 5 \\
\hline C & 0,25 & 0,33 & 1 & 3 \\
\hline D & 0,17 & 0,20 & 0,33 & 1 \\
\hline Jumlah & 1,75 & 4,53 & 8,33 & 15,00 \\
\hline
\end{tabular}


Jurnal Inkofar * Volume 1 No. 1, Juli 2017 * ISSN: 2615-3645 (Print) / 2581-2920 (Online)

Tersedia secara online di: http://www.politeknikmeta.ac.id/meta/ojs/

2. Membuat matriks nilai sub kriteria

Tabel 8. Matrik prioritas sub kriteria

\begin{tabular}{|c|c|c|c|c|}
\hline & A & B & C & D \\
\hline A & 0,57 & 0,66 & 0,48 & 0,40 \\
\hline B & 0,19 & 0,22 & 0,36 & 0,33 \\
\hline C & 0,14 & 0,07 & 0,12 & 0,20 \\
\hline D & 0,10 & 0,04 & 0,04 & 0,07 \\
\hline
\end{tabular}

Ket :

Jumlah Perbaris A: $(0.57+0.66+0.48+0.40)=2.11$

Prioritas $=$ Jumlah Baris / Jumlah Sub Kriteria

Prioritas A : $2.11: 4=0.5283$

Prioritas Sub Kriteria $=$ Prioritas : nilai tertinggi pada tabel subkriteria.

Prioritas sub kriteria $=0.5283: 0.5283=1.0$

Semua hasil kolom dicari sesuai dengan rumus diatas.

3. Membuat matrik penjumlahan setiap baris

Tabel 9. Hasil penjumlahan setiap baris

\begin{tabular}{|c|c|c|c|c|c|}
\hline & A & B & C & D & Jumlah \\
\hline A & 0,53 & 0,83 & 0,54 & 0,37 & 2,26 \\
\hline B & 0,18 & 0,28 & 0,40 & 0,31 & 1,16 \\
\hline C & 0,13 & 0,09 & 0,13 & 0,18 & 0,54 \\
\hline D & 0,09 & 0,06 & 0,04 & 0,06 & 0,25 \\
\hline
\end{tabular}

Nilai 0,57 pada baris dan kolom A didapat dari perkalian antara nilai prioritas baris A pada tabel matrik nilai kriteria dikalikan dengan nilai baris - kolom A pada tabel matrik perbandingan berpasangan. Nilai yang lain diperoleh dengan cara yang sama. Nilai jumlah didapat dari penjumlah nilai pada masing-masing baris sub kriteria.

4. Perhitungan Rasio Kosistensi

Tabel 10. Perhitungan CR sub kriteria

\begin{tabular}{|c|c|c|c|}
\hline & Jumlah & Prioritas & Hasil \\
\hline A & 2,26 & 0,53 & 2,79 \\
\hline B & 1,16 & 0,28 & 1,44 \\
\hline C & 0,54 & 0,13 & 0,68 \\
\hline D & 0,25 & 0,06 & 0,31 \\
\hline
\end{tabular}

Jumlah (penjumlahan dari nilai hasil) $=5.22$

$\mathrm{n}$ (jumlah kriteria) $=4$

$\lambda$ maks (jumlah/n) $=1,3041$

$\mathrm{CI}(\lambda$ maks $-\mathrm{n}) /(\mathrm{n}-1)=-0,899$

$\mathrm{CR}(\mathrm{CI} / \mathrm{IR}$ (lihat pada tabel index random) $=-0.998$

Karena nilai $\mathrm{CR}<=0.1$, maka rasio kosistnsi perhitungan dapat diterima.

Prioritas hasil perhitungan kemudian dituangkan ke dalam matriks hasil yang terlihat pada Tabel 10. 
Jurnal Inkofar * Volume 1 No. 1, Juli 2017 * ISSN: 2615-3645 (Print) / 2581-2920 (Online)

Tersedia secara online di: http://www.politeknikmeta.ac.id/meta/ojs/

Tabel 11. Hasil perhitungan setiap prioritas kriteria dan subkriteria

\begin{tabular}{|c|c|c|c|c|}
\hline $\mathrm{A}$ & $\mathrm{B}$ & $\mathrm{C}$ & $\mathrm{D}$ & $\mathrm{E}$ \\
0,2962 & 0,1663 & 0,0935 & 0,0512 & 0,3929 \\
\hline $\mathrm{A}$ & $\mathrm{A}$ & $\mathrm{A}$ & $\mathrm{A}$ & $\mathrm{A}$ \\
1,0000 & 1,0000 & 1,0000 & 1,0000 & 1,0000 \\
\hline $\mathrm{B}$ & $\mathrm{B}$ & $\mathrm{B}$ & $\mathrm{B}$ & $\mathrm{B}$ \\
0,5226 & 0,6032 & 0,5170 & 0,5708 & 0,5950 \\
\hline $\mathrm{C}$ & $\mathrm{C}$ & $\mathrm{C}$ & $\mathrm{C}$ & $\mathrm{C}$ \\
0,2538 & 0,3642 & 0,2189 & 0,2390 & 0,3458 \\
\hline $\mathrm{D}$ & $\mathrm{D}$ & $\mathrm{D}$ & $\mathrm{D}$ & $\mathrm{D}$ \\
0,1164 & 0,1564 & 0,1010 & 0,1116 & 0,2060 \\
\hline
\end{tabular}

Seandainya diberikan dari data tiga orang calon anggota sebagai berikut :

Tabel 12. Contoh Data

\begin{tabular}{|c|c|c|c|c|c|}
\hline & A & B & C & D & E \\
\hline A & Baik & $\begin{array}{c}\text { Cukup } \\
\text { Baik }\end{array}$ & $\begin{array}{c}\text { Sangat } \\
\text { Baik }\end{array}$ & $\begin{array}{c}\text { Cukup } \\
\text { Baik }\end{array}$ & $\begin{array}{c}\text { Sangat } \\
\text { Baik }\end{array}$ \\
\hline B & $\begin{array}{c}\text { Sangat } \\
\text { Baik }\end{array}$ & $\begin{array}{c}\text { Sangat } \\
\text { Baik }\end{array}$ & Baik & $\begin{array}{c}\text { Cukup } \\
\text { Baik }\end{array}$ & Baik \\
\hline C & $\begin{array}{c}\text { Cukup } \\
\text { Baik }\end{array}$ & Baik & $\begin{array}{c}\text { Cukup } \\
\text { Baik }\end{array}$ & $\begin{array}{c}\text { Sangat } \\
\text { Baik }\end{array}$ & Baik \\
\hline
\end{tabular}

Maka hasilnya adalah :

Tabel 13. Hasil Perhitugan Contoh Data

\begin{tabular}{|c|c|c|c|c|c|c|}
\hline & $\mathrm{A}$ & $\mathrm{B}$ & $\mathrm{C}$ & $\mathrm{D}$ & $\mathrm{E}$ & Total \\
\hline $\mathrm{A}$ & 0.1548 & 0.0606 & 0.0205 & 0.0512 & 0.3929 & 0.6799 \\
\hline $\mathrm{B}$ & 0.2962 & 0.1663 & 0.0205 & 0.0292 & 0.2338 & 0.7459 \\
\hline $\mathrm{C}$ & 0.0752 & 0.1003 & 0.0935 & 0.0292 & 0.1359 & 0.4341 \\
\hline
\end{tabular}

Nilai 0.1548 pada pelamar A pada kolom pengetahuan didapatkan dari hasil perkalian nilai prioritas pengetahuan dengan nilai sub prioritas pada sub kriteria pengetahuan, begitupun dengan nilai lainnya dilakukan dengan cara yang sama. Total didapatkan dari nilai penjumlahan pada tiap baris penilaian. Maka dari hasil total score tertinggilah yang nantinya akan diprioritaskan untuk dapat diterima.

\subsection{Perancangan Aplikasi}

Perancangan aplikasi sistem pengamilan keputusan ini, dirancang menggunakan alat bantu berupa UML (Unified Modelling Language) agar mempermudah memindahkan konsep sistem yang dirancang kedalam bentuk program.

\subsubsection{Use Case Diagram}

Use case diagram adalah gambaran graphical dari beberapa atau semua aktor, use case, dan interaksi diantara komponen-komponen tersebut yang memperkenalkan suatu sistem yang akan dibangun digunakan untuk menjelaskan bagaimana langkah-langkah yang seharusnya dikerjakan oleh sistem. Use case diagram menjelaskan manfaat suatu sistem jika dilihat menurut pandangan orang yang berada di luar sistem. Diagram ini menunjukkan fungsionalitas suatu sistem atau kelas dan bagaimana sistem tersebut berinteraksi dengan dunia luar. Adapun use case pada aplikasi ini adalah sebagai berikut: 
Jurnal Inkofar * Volume 1 No. 1, Juli 2017 * ISSN: 2615-3645 (Print) / 2581-2920 (Online)

Tersedia secara online di: http://www.politeknikmeta.ac.id/meta/ojs/

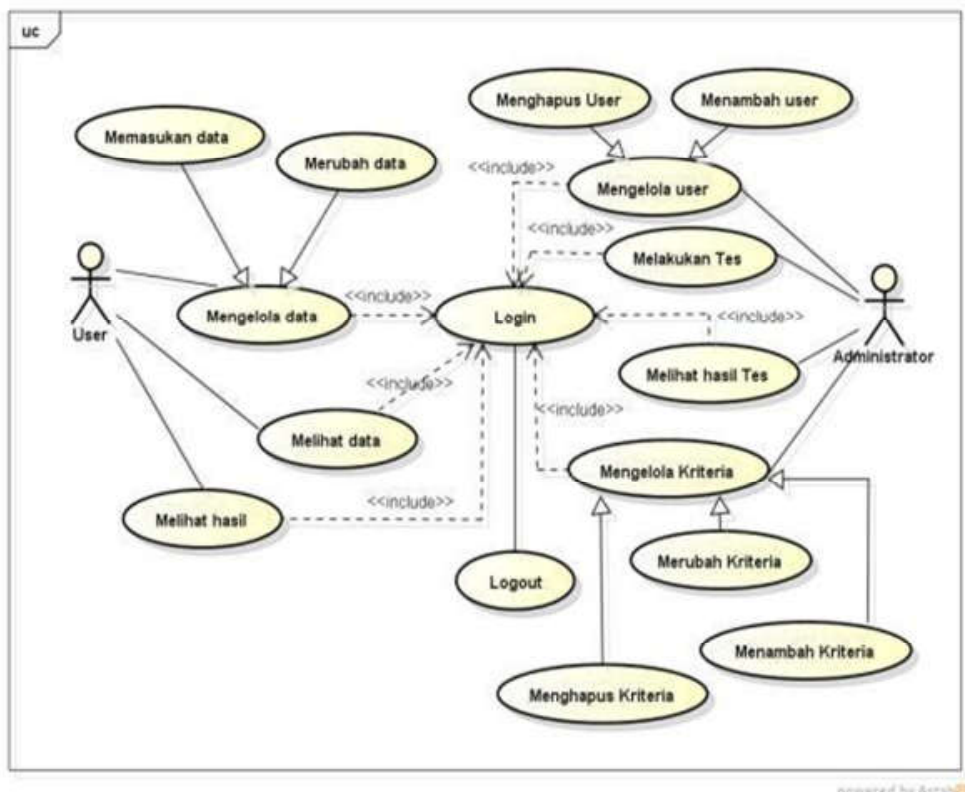

Gambar 2. Use Case Diagram

\subsubsection{Activity Diagram Admin}

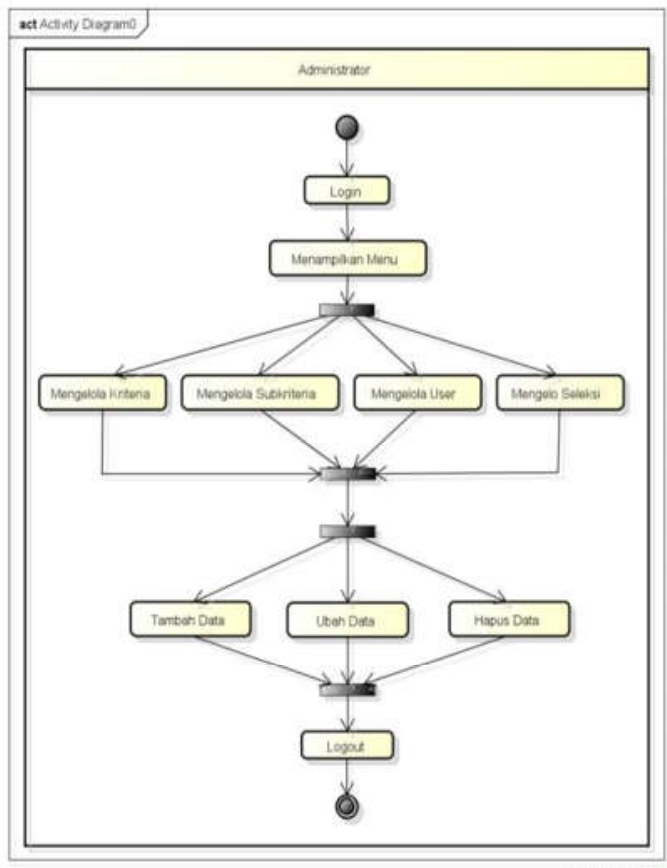

Gambar 3. Activity Diagram Admin

Pada Gambar 3 di atas, administrator menggambarkan segala aktivitas yang bisa dilakukan admin terhadap aplikasi yang sedang berjalan serta bisa memilih aktivitas yang akan dilakukan melalui menu-menu pilihan yang ada. Sistem menggambarkan segala aktifitas yang digunakan untuk segala proses pengelolaan data. 
Jurnal Inkofar * Volume 1 No. 1, Juli 2017 * ISSN: 2615-3645 (Print) / 2581-2920 (Online)

Tersedia secara online di: http://www.politeknikmeta.ac.id/meta/ojs/

\subsubsection{Activity Diagram User}

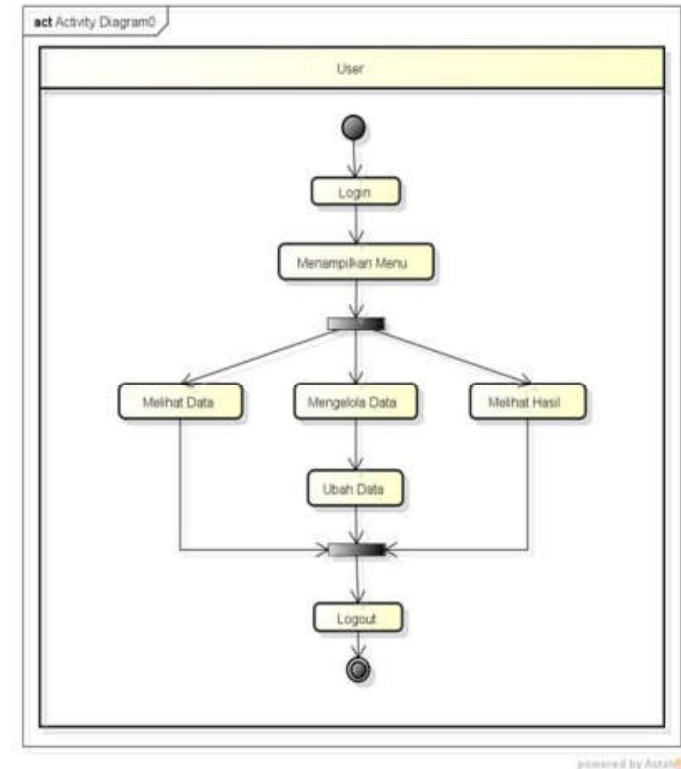

Gambar 4. Activity Diagram User

Pada Gambar 4 di atas, user menggambarkan segala aktivitas yang bisa dilakukan user terhadap aplikasi yang sedang berjalan serta bisa memilih aktivitas yang akan dilakukan melalui menumenu pilihan yang ada. Sistem menggambarkan segala aktifitas yang digunakan untuk segala proses pengelolaan data.

\subsubsection{Class Diagram}

Class Diagram menggambarkan keadaan (atribut/properti) suatu sistem, sekaligus menawarkan layanan untuk memanipulasi keadaan tersebut (metoda/fungsi).

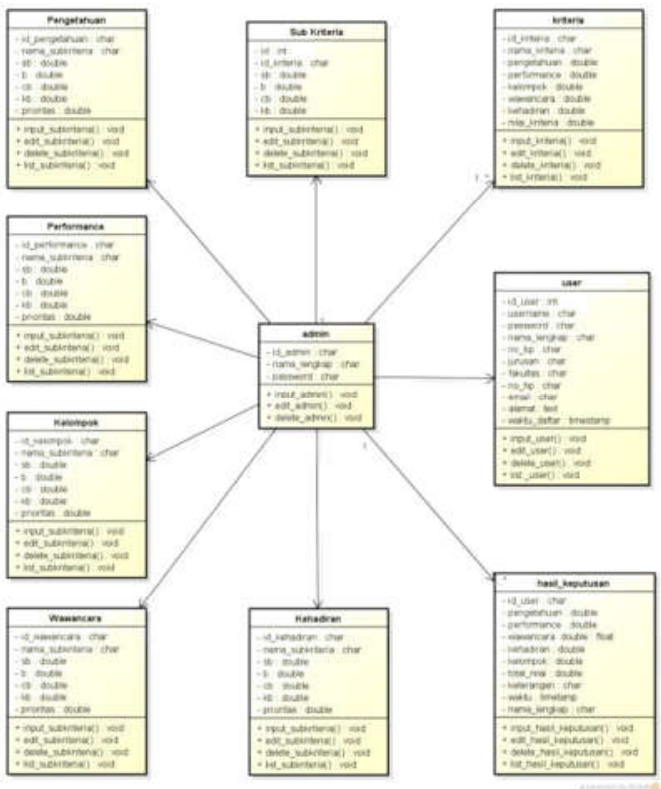

Gambar 5. Class Diagram 


\section{HASIL DAN PEMBAHASAN}

Implementasi program merupakan realisasi dari hasil perancangan yang telah dibuat dengan UML, Perancangan sistem yang sudah dibuat dikonversikan ke dalam bentuk program aplikasi. Pengujian dan implementasi sistem bertujuan untuk melihat apakah sistem yang dirancang sudah sesuai dengan apa yang diinginkan atau belum, setelah dilakukannya pengujian dan implementasi, kualitas sebuah sistem akan terlihat. Berikut ini adalah implementasi dari perancangan sistem pengambilan keputusan penerimaan anggota baru UKM IT Cybernetix.

\subsection{Halaman Awal Website.}

Halaman awal website merupakan halaman yang akan ditampilkan ketika pertama kali membuka sistem aplikasi pengambilan keputusan ini. Halaman website ini berisikan logo dari UKM IT Cybernetix dan form login yang akan digunakan user digunakan user, baik administrator maupun calon anggota.

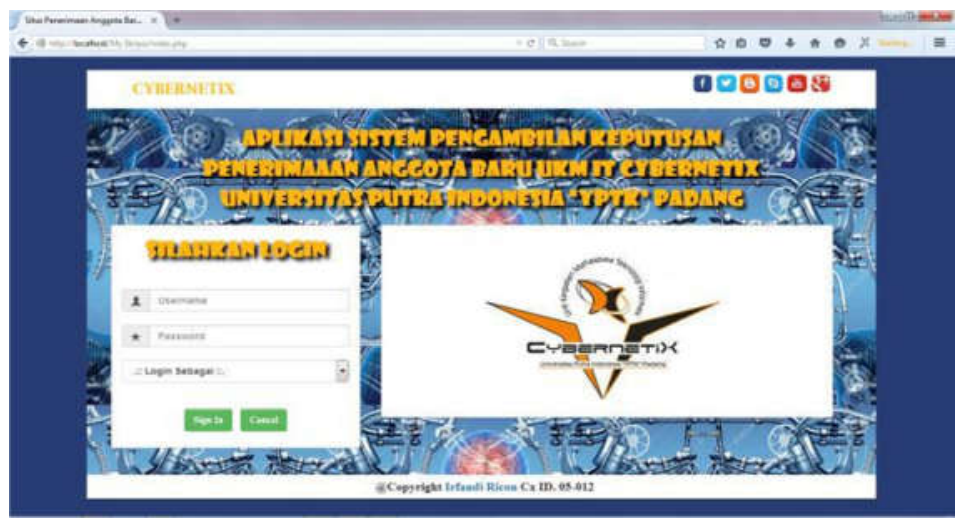

Gambar 6. Halaman Awal Website

\subsection{Halaman Index Admin}

Halaman index admin merupakan halaman awal yang digunakan administrator setelah login. Halaman ini berisikan keterangan selamat datang kepada administrator.

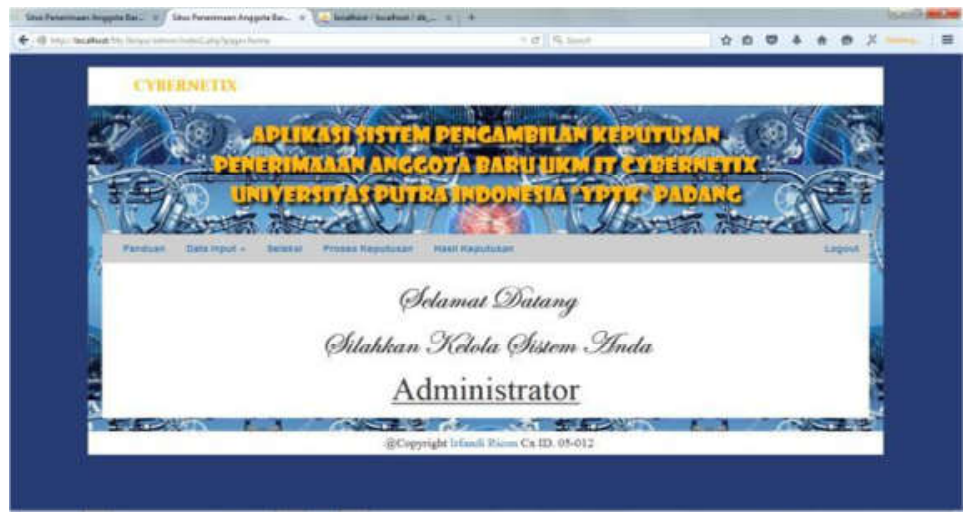

Gambar 7. Halaman Index Admin

\subsection{Halaman Seleksi}

Halaman ini berisikan data dari user yang akan dilakukan seleksi. Pada halaman ini terdapat beberapa aturan dan keterangan dari penilaian yang berada pada sisi kiri website. Keterangan ini jugalah nantinya yang akan dijadikan pedoman dalam penilaian. 
Jurnal Inkofar * Volume 1 No. 1, Juli 2017 * ISSN: 2615-3645 (Print) / 2581-2920 (Online)

Tersedia secara online di: http://www.politeknikmeta.ac.id/meta/ojs/

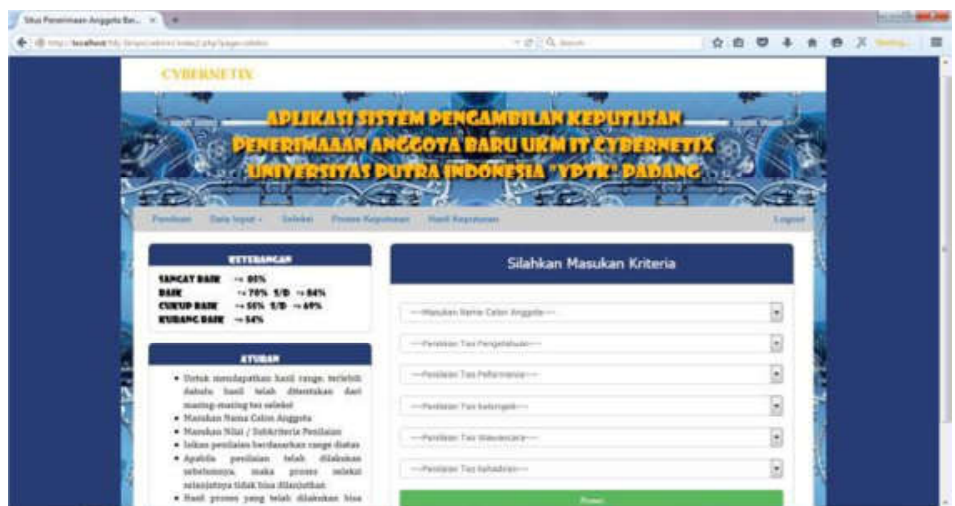

Gambar 8. Halaman Seleksi

\subsection{Proses Keputusan Sub Kriteria}

Halaman ini berisikan data perbandingan sub kriteria yang digunakan berupa nilai-nilai seperti pada halaman panduan yang telah ditampilkan. Nilai inilah yang nantinya akan diproses sesuai dengan rumus perhitungan metode Analytic Hierarchy Process (AHP) yang telah dimasukan kedalam sistem aplikasi.

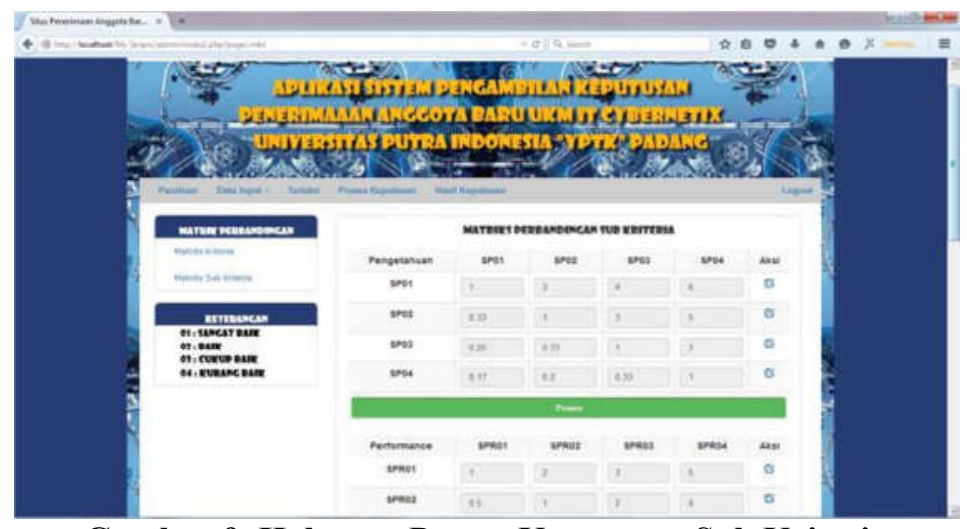

Gambar 9. Halaman Proses Keputusan Sub Kriteria

\subsection{Hasil Proses Keputusan Perbandingan}

Halaman ini berisikan hasil dari proses perhitungan yang telah dilakukan oleh sistem baik itu perbandingan kriteria, maupun perbandingan sub kriteria dengan menggunakan rumus perhitungan yang sama.

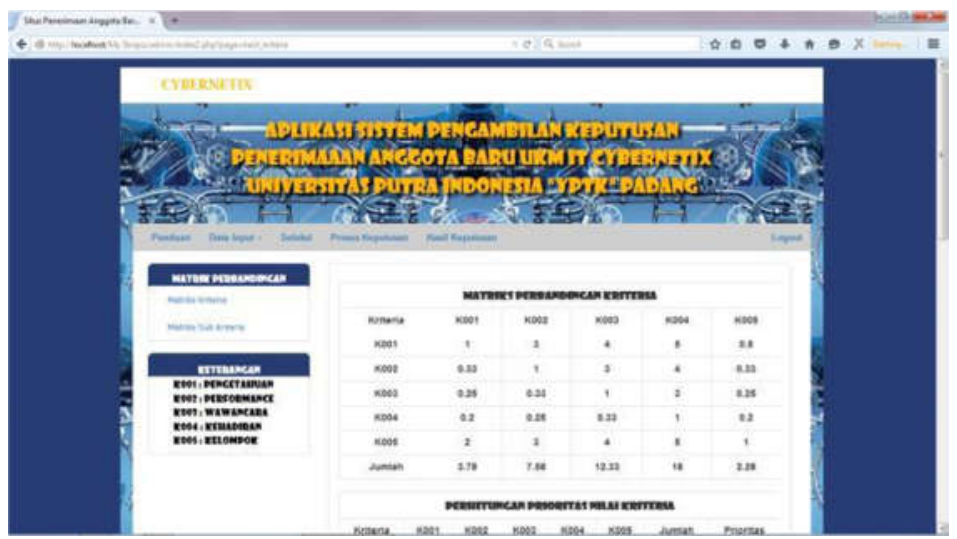

Gambar 10. Halaman Proses Keputusan Perbandingan 
Jurnal Inkofar * Volume 1 No. 1, Juli 2017 * ISSN: 2615-3645 (Print) / 2581-2920 (Online)

Tersedia secara online di: http://www.politeknikmeta.ac.id/meta/ojs/

\subsection{Halaman Hasil Seleksi}

Halaman ini berisi daftar nama calon anggota yang telah dilakukan proses seleksi oleh administrator.

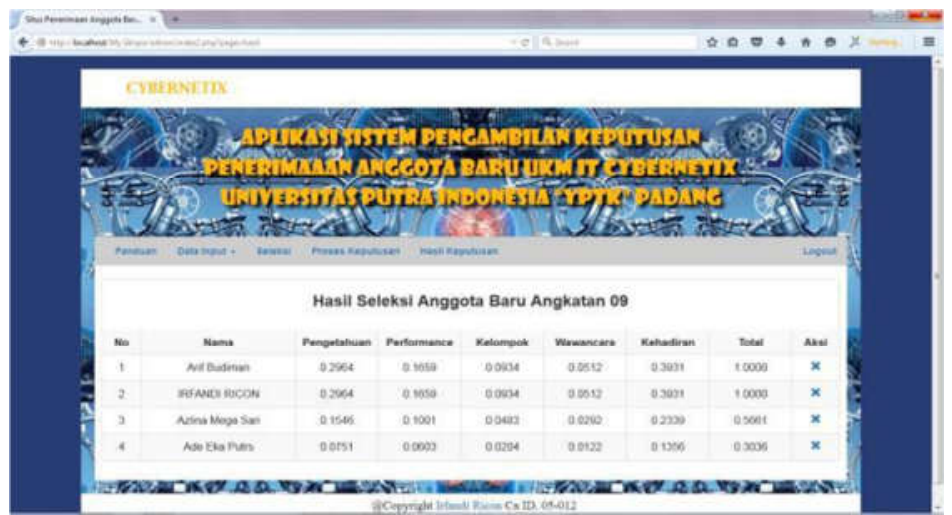

Gambar 11. Halaman Hasil Seleksi

\subsection{Halaman Index User}

Halaman index user merupakan halaman awal yang digunakan calon anggota setelah login. Halaman ini berisikan keterangan selamat datang kepada calon anggota

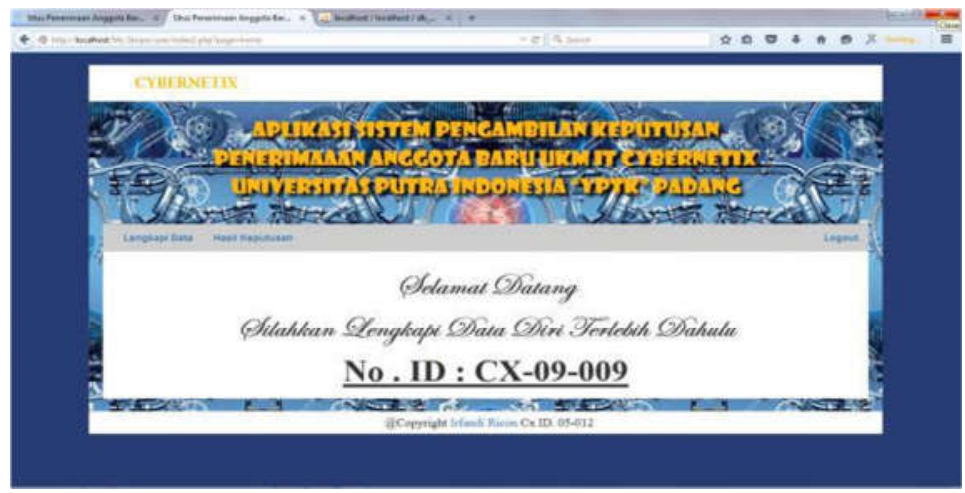

Gambar 12. Halaman Index User

\subsection{Halaman Hasil Seleksi User}

Halaman ini berisikan keterangan dari data yang telah diproses oleh administrator menggunkan sistem apakah calon anggota lulus atau tidak pada penerimaan anggota baru

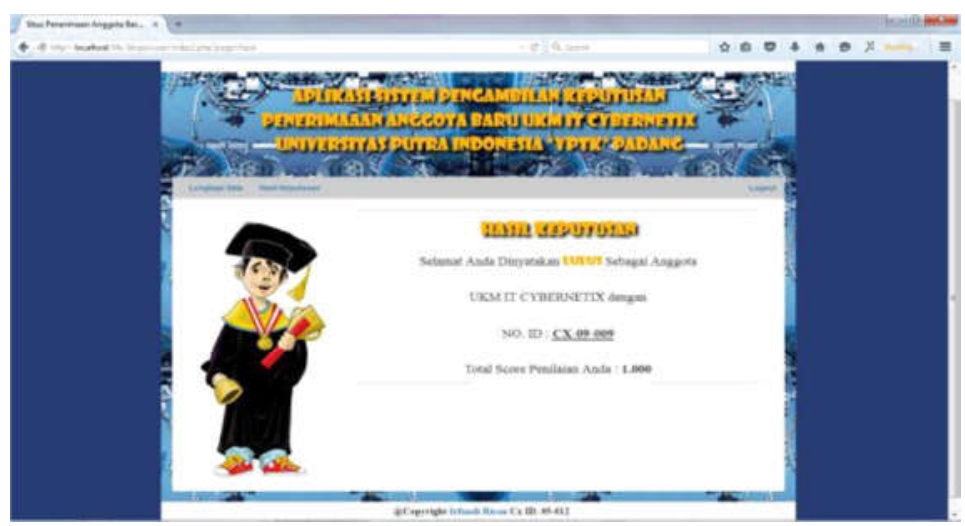

Gambar 13. Halaman Hasil Seleksi User 


\section{KESIMPULAN}

Berdasarkan hasil dari analisa, perancangan aplikasi sistem pengambilan keputusan dalam penerimaan anggota baru pada UKM IT Cybernetix menggunakan metode Analytic Hierarchy Process (AHP) dengan bahasa pemrograman php \& mysql, maka dapat diambil kesimpulan, yaitu :

1. Dengan sistem pendukung keputusan yang menerapkan metode AHP berbasis web dalam pengambilan keputusan sangat membantu panitia dalam menghasilkan keputusan yang mutlak.

2. Dengan telah ditentukannya kriteria dalam penerimaan anggota baru dapat membantu panitia menghasilkan anggota baru yang berbakat pada setiap bidang keahliannya.

3. Dengan adanya aplikasi sistem pengambilan keputusan ini yang menerapkan metode AHP dapat menghasilkan anggota baru yang berdedikasi tinggi serta memiliki loyalitas yang besar pada UKM IT Cybernetix sesuai dengan kriteria yang telah ditetapkan dalam penerimaan.

\section{DAFTAR PUSTAKA}

Fowler, Martin. 2004. UML Distilled. Yogyakarta: Andi.

Hanum, Yuhilza. Software Engineering (Rekayasa Perangkat Lunak). Jakarta : Erlangga.

Komang, I Setia Buana.2014. Jago Pemrograman PHP. Bandung: Dunia Komputer.

Magdalena, Hilyah. 2012. Sistem pendukung keputusan untuk menentukan mahasiswa lulusan terbaik di perguruan tinggi (studi kasus STMIK ATMA LUHUR Pangkal Pinang).Yogyakarta: Seminar Nasional Teknologi Informasi dan Komunikasi.

Mulyanto, Aunur R. 2008. Rekayasa Perangkat Lunak, Jilid 1. Jakarta: Direktur Pembinaan Sekolah Menengah Kejuruan.

Oktavian, Diar, Puji. 2013. Membuat Powerfull Menggunakan PHP. Yogyakarta: Mediakom.

Peranginangin, Kasiman. 2014. Aplikasi Web dengan PHP \& MySQL. Yogyakarta : Andi.

S, Rosa A. dan M. Shalahuddin, 2013. Rekayasa Perangkat Lunak Terstruktur dan Berorientasi Objek. Bandung : Informatika.

Sidik, Betha, 2012. Pemrograman Web PHP, Bandung : Informatika.

Subakti, Irfan. 2002. Sistem Pendukung Keputusan (Decision Support System). Teknik Informatika Institut Teknologi Sepuluh Nopember.

Syukur, Abdul, Tyas Catur P dkk., 2010. Penerapan Metode Analytical Hierarchi Process dalam penerimaan karyawan pada PT. Pasir Besi Indonesia. Pascasarjana Teknik Informatika Univeristas Dian Nuswantoro 